\title{
Purification of the Vitamin $B_{12}$-Active Material from the Haemoflagellate, Crithidia fasciculata
}

\author{
BY F. SANDERS AND G. R. SEAMAN \\ Carter Physiology Laboratory, University of Texas Medical Branch, Galveston, Texas, U.S.A.
}

\section{(Received 4 December 1958)}

Extracts of the haemoflagellate, Crithidia fasciculata, replace vitamin $\mathrm{B}_{12}$ for the growth of Escherichia coli 113-3, for the soil bacterium referred to as 'Lochhead 38' and for Euglena gracilis (Seaman \& Sanders, 1957). The substance differs, however, from members of the $B_{12}$ series of vitamins in that its activity is completely destroyed by exposure for $24 \mathrm{hr}$. at room temperature to $\mathrm{pH} 3.5$ or 10.7 (Seaman \& Sanders, 1957). The $\mathrm{B}_{12}$ vitamins are stable at $\mathrm{pH} 3.5$ and at $\mathrm{pH} 10.7$ undergo only slight degradation, with the release of unidentified fragments which replace cyanocobalamin in the growth of $E$. coli 113-3; alkaline destruction of the Crithidia material does not release such fragments. In spite of these differences of stability in acid and alkali, the biological activity of the material from Crithidia suggests that it is a functional member of the $B_{12}$ series of vitamins.

The present report describes a procedure for the partial purification of the vitamin $B_{12}$-like material from Crithidia and describes some of its biological properties. The active material will be referred to as vitamin $B_{12}(C r)$. It is not suggested that this be adopted as a term for a newly described member of the vitamin $B_{12}$ series, but rather that the term is used merely for convenience of reference.

\section{EXPERIMENTAL}

\section{Materials used and assay procedures}

Crithidia fasciculata. Stock cultures were grown in tubes containing the yeast hydrolysato-liver concentrate-haemin medium described by Cowperthwaite, Weber, Packer \& Hutner (1953). Cultures were grown at $25^{\circ}$, and transfers were made at monthly intervals. Large-scale cultures were grown for 4-5 days at $25^{\circ}$ in stainless-steel drums (capacity $200 \mathrm{l}$.) containing $50 \mathrm{l}$. of the Cowperthwaite 'final' synthetic medium (Cowperthwaite et al. 1953) to which sterile glucose and vitamins were added after autoclaving. Each drum was inoculated with 11 . of a 4- to 5-day-old culture which had been grown in the same synthetic medium. Aeration was provided by drawing air through the drums by means of a vacuum line.

To obtain information about the physiological importance of vitamin $B_{12}(C r)$, the effect of the purified vitamin on the growth of Crithidia was studied. Assays were carried out in $25 \mathrm{ml}$. nephelometer flasks containing $4 \mathrm{ml}$. of the 'final' synthetic medium of Cowperthwaite et al. (1953); sorbitol $(1.5 \%, w / v)$ was used as energy source. The flasks were covered with aluminium caps. Both flasks and caps were obtained from the Bellco Glass Co., Vineland, New Jersey, U.S.A. Flasks were inoculated with one drop of a 1:20 dilution of the stock culture, the diluent being the synthetic medium. The cultures were incubated at $25^{\circ}$ and growth was periodically measured in a Klett-Summerson photometer equipped with a green filter (Klett-Summerson no. 65).

Vitamin $\mathrm{B}_{18}$ assays. These were carried out by the filterpaper disk method with $E$. coli 113-3, details of which have been described (Sanders \& Seaman, 1959). Purified samples of vitamin $\mathrm{B}_{12}(\mathrm{Cr})$ were assayed with the chrysomonad, Ochromonas malhamensis, which is specific in its requirement for cyanocobalamin (Ford \& Hutner, 1955). Stock cultures of this organism were maintained on the basal medium described by Hutner, Bach \& Ross (1956), supplemented with $0 \cdot 1 \mu \mathrm{mg}$. of cyanocobalamin $/ \mathrm{ml}$. Assays were carried out in $25 \mathrm{ml}$. nephelometer flasks containing $5 \mathrm{ml}$. of basal medium and covered with aluminium caps. One drop of a $1: 20$ dilution of the stock culture was used as inoculum, the diluent being unsupplemented basal medium. Flasks were illuminated with a $40 \mathrm{w}$ fluorescent lamp (Ken-Rad, F 40, T-12, type CW) at a distance of $20 \mathrm{~cm}$. and incubated for 5 days at $25^{\circ}$. Growth was measured in a KlettSummerson photometer with a green filter (KlettSummerson no. 65).

\section{Extraction and purification of vitamin $\mathrm{B}_{12}(\mathrm{Cr})$}

Preliminary extraction. Haemoflagellates were collected by passage through a Sharples supercentrifuge at $4^{\circ}$. The organisms were washed by centrifuging twice with $0.1 \mathrm{M}$ phosphate buffer, $\mathrm{pH} 8.5$, once with $0.9 \% \mathrm{NaCl}$ and once with water. They were then suspended in $0.03 \mathrm{~N}-\mathrm{HCl}$ to give a concentration of approx. $80 \mathrm{mg}$. of solids $/ \mathrm{ml}$. After the addition of $0.5 \mathrm{mg}$. of $\mathrm{NaCN} / \mathrm{ml}$., hydrolysis was carried out in a boiling-water bath for $45 \mathrm{~min}$. After cooling to $4^{\circ}$ the $\mathrm{pH}$ was adjusted to $4 \cdot 5-5 \cdot 0$ with $2 \mathrm{~N}-\mathrm{KOH}$ and the insoluble material was removed by centrifuging.

Purification of extract. Ethanol $\left(95 \%, v / v ; 5\right.$ vol.) at $4^{\circ}$ was added slowly to the extract with stirring, and the mixture was allowed to stand at $4^{\circ}$ for $4 \mathrm{hr}$. The precipitate was removed by centrifuging and the ethanolic extract was evaporated to near dryness in vacuo. The residue was dissolved in a minimum volume of $3 \mathrm{mN}-\mathrm{HCl}$ and was extracted into 5 vol. of water-saturated phenol. The phenol-rich layer was extracted three times with equal volumes of water and the protein-free aqueous solutions were combined and evaporated to dryness in vacuo. The residue was dissolved in the minimum volume of $0 \cdot 05 \mathrm{~m}$-phosphate buffer, $\mathrm{pH} 6 \cdot 0$. The redissolved extract was taken up in a small amount of ether-washed Celite 535 (Johns-Manville Co. Ltd.) and was placed on top of a 3 in. $\times 30$ in. chromatographic column packed with Celite 535 (Swim \& Krampitz, 1953). Several 
Table 1. Summary of purification of vitamin $\mathrm{B}_{12}(\mathrm{Cr})$

Vitamin activity was assayed by the filter-paper-disk method with $E$. coli 113-3.

\begin{tabular}{|c|c|c|c|c|}
\hline Fraction & $\begin{array}{l}\text { Total dry } \\
\text { wt. of solids } \\
\text { (mg.) }\end{array}$ & $\begin{array}{c}\text { Total } \\
\text { volume } \\
\text { (ml.) }\end{array}$ & $\begin{array}{c}\text { Total vitamin } \\
\text { B }_{12} \text { activity } \\
\text { ( } \mu \mathrm{mg} .)\end{array}$ & $\begin{array}{l}\text { Activity per mg. } \\
\text { dry wt. of solids } \\
\text { ( } \mu \mathrm{mg} .)\end{array}$ \\
\hline $\begin{array}{l}\text { Cell extract } \\
\text { Phosphate extract }\end{array}$ & $\begin{array}{r}184800 \\
3720\end{array}$ & $\begin{array}{r}2400 \\
620\end{array}$ & $\begin{array}{l}720 \\
625\end{array}$ & $\begin{array}{l}0.004 \\
0 \cdot 17\end{array}$ \\
\hline Celite eluate & 11 & 25 & 250 & $22 \cdot 7$ \\
\hline
\end{tabular}

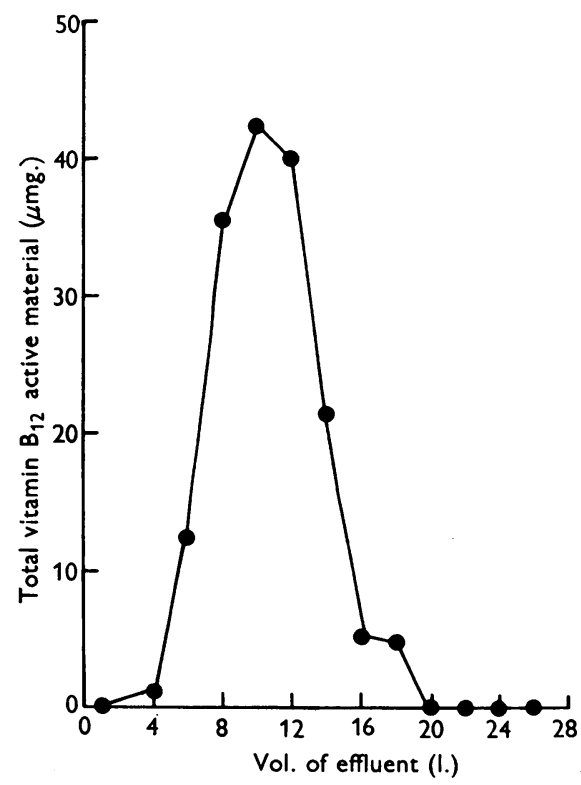

Fig. 1. Elution of vitamin $B_{18}(C r)$ from chromatographic column packed with Celite 535. The solvent system was the organic phase of a mixture of butan-2-ol-0.05 Mphosphate buffer (pH 6.0)-4\% (w/v) KCN (100:50:0.25, by vol.). Vitamin $B_{12}$ activity was assayed by the filterpaper-disk method with $E$. coli 113-3.

litres of the organic phase of butan-2-ol-0.05 M-phosphate buffer (pH 6.0)-4\% (w/v) KCN (100:50: $0 \cdot 25$, by vol.) were passed through the column under a pressure sufficient to deliver 2 l. of eluate/hr., and collections were made of successive 11. volumes. Fig. 1 shows that the maximum vitamin $B_{18}(\mathrm{Cr})$ activity was eluted between 8 and 121 . These five fractions of tawny-coloured solution were combined and evaporated in vacuo to a volume of $25 \mathrm{ml}$. The concentrate was a reddish brown colour. The degree of purification achieved by the procedure is shown in Table 1 .

\section{RESULTS}

Activity of vitamin $\mathrm{B}_{12}(\mathrm{Cr})$ for Ochromonas. Fig. 2 shows that purified vitamin $B_{12}(C r)$ replaces cyanocobalamin for the growth of Ochromonas; however, it is only one-hundredth as active, on the basis of cyanocobalamin equivalents for growth of $E$. coli 113-3. When added in the presence of cyano-

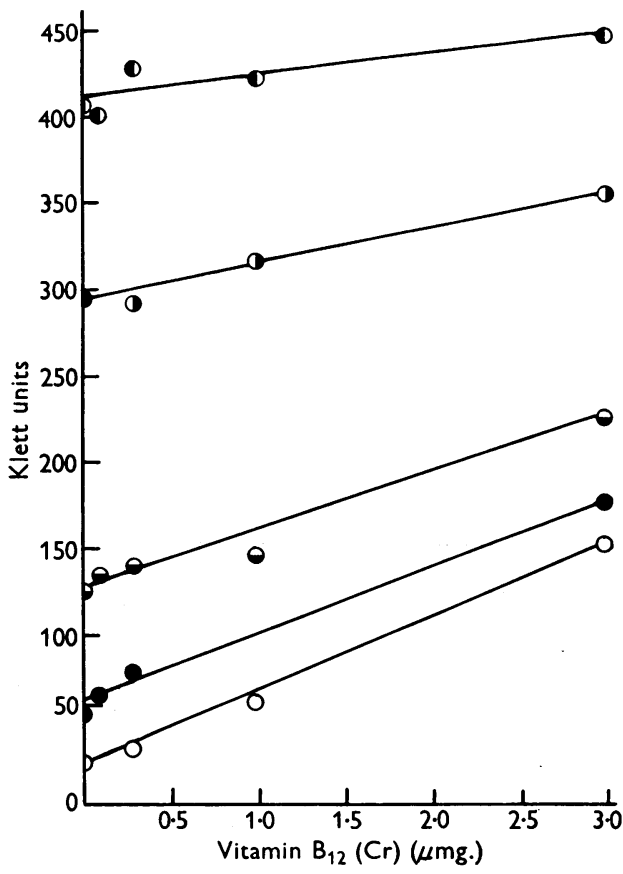

Fig. 2. Growth response of Ochromonas malhamensis to vitamin $B_{12}(C r)$ and to combinations of vitamin $B_{12}(C r)$ with cyanocobalamin. The amounts of added cyanocobalamin and vitamin $\mathrm{B}_{12}(\mathrm{Cr})$ were determined by assay with $E$. coli 113-3. O, No added cyanocobalamin; 0 , $0.01 \mu \mathrm{mg}$. of cyanocobalamin; $\ominus, 0.03 \mu \mathrm{mg}$. of cyanocobalamin; $0,0.1 \mu \mathrm{mg}$. of cyanocobalamin; $0,1.0 \mu \mathrm{mg}$. of cyanocobalamin.

cobalamin, vitamin $B_{12}(C r)$ augments the growth response. As illustrated in the figure, augmentation is maximal at low levels of cyanocobalamin. As the concentration of cyanocobalamin is increased the stimulation by vitamin $\mathrm{B}_{12}(\mathrm{Cr})$ decreases, until at levels of cyanocobalamin which support halfmaximal to maximal growth, addition of vitamin $\mathrm{B}_{12}(\mathrm{Cr})$ is without appreciable effect.

Effect of vitamin $\mathrm{B}_{12}(\mathrm{Cr})$ on growth of Crithidia. Fig. $3 A$ shows that addition of vitamin $\mathrm{B}_{12}(\mathrm{Cr})$ to cultures of Crithidia shortened the lag period and increased the total growth. Although the shortening of the lag phase of growth is not proportional to the amount of vitamin $\mathrm{B}_{12}(\mathrm{Cr})$ added, Fig. $3 B$ 

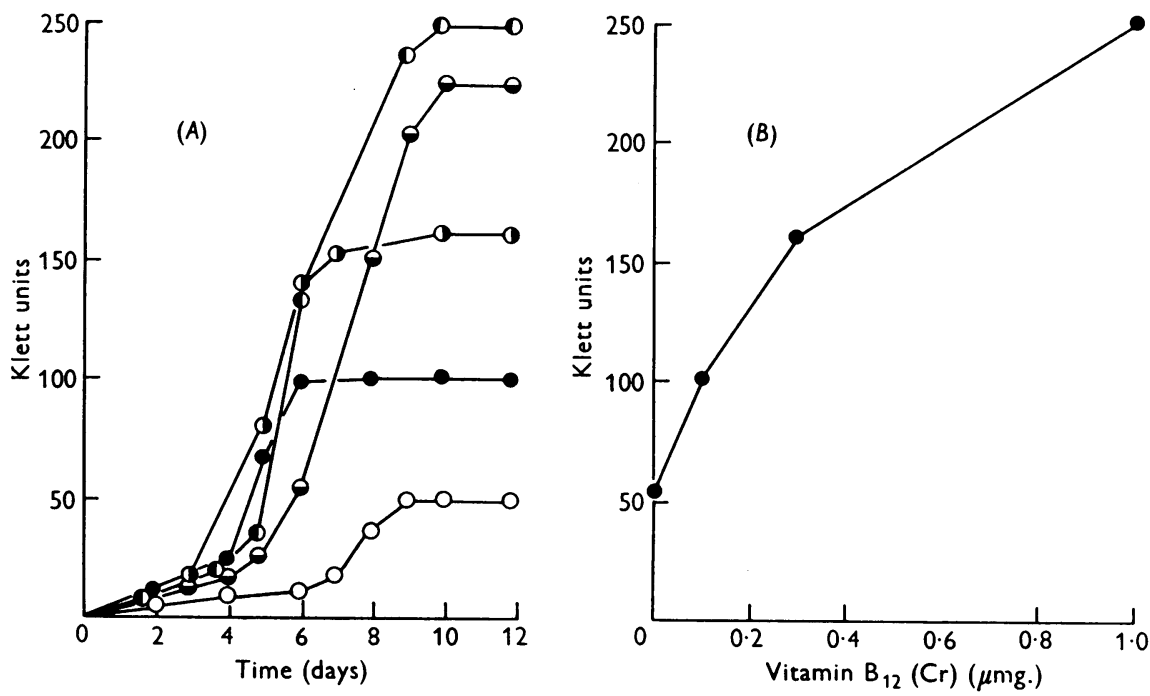

Fig. 3. Effect of vitamin $B_{12}(C r)$ on growth of Crithidia fasciculata. The amounts of vitamin $B_{12}(C r)$ added were determined as vitamin $\mathrm{B}_{12}$ equivalents by assay with $E$. coli 113-3 by the filter-paper-disk method. $(A)$ Time course of growth response. $O$, No added vitamin; $0,0.1 \mu \mathrm{mg}$. of vitamin $B_{12}(\mathrm{Cr}) ; O, 0.3 \mu \mathrm{mg}$. of vitamin $B_{12}(C r)$; $\vartheta, 1.0 \mu \mathrm{mg}$. of vitamin $B_{12}(C r)$; $0,3.0 \mu \mathrm{mg}$. of vitamin $B_{12}(C r)$. (B) Effect of vitamin $B_{12}(C r)$ on total growth (12 days' incubation) achieved by Crithidia. Data were taken from $(A)$.

shows that the growth finally attained is dependent upon the concentration of added vitamin. Addition of either cyanocobalamin or factor $B$ (the compound formed by removal of the nucleotide portion of cyanocobalamin) had no effect on the growth response.

It appears that vitamin $B_{12}(C r)$ is a growth factor for Crithidia and that the growing organisms are capable of synthesizing it in limited amounts. The growth of this organism is not stimulated by cyanocobalamin or by factor $B$. The vitamin is apparently also not identical with biopterin (2-amino-4hydroxy - 6 - (1:2 - dihydroxypropyl) - pteridine), the pteridine which under certain conditions is required for the growth of Crithidia (Patterson, Broquist, Albrecht, von Saltza \& Stokstad, 1955) since in media containing large amounts of folic acid, as does the medium used in the experiments shown in Fig. 3, the pteridine requirement is abolished.

\section{SUMMARY}

1. The vitamin $B_{12}$ activity [vitamin $B_{12}(C r)$ ] from the haemoflagellate, Crithidia fasciculata, has been purified 5500-fold with a recovery of $34 \%$ of the initial activity present in cell extracts.

2. Vitamin $B_{12}(C r)$ is approximately onehundredth as active as cyanocobalamin for the growth of Ochromonas malhamensis.

3. The growth of Crithidia is stimulated by vitamin $B_{12}(\mathrm{Cr})$; the degree of stimulation is dependent upon the concentration of vitamin added.

This investigation was aided by a grant (E-159) from the National Institute of Allergy and Infectious Diseases, U.S. Public Health Service, and from the Elsa U. Pardee Foundation.

\section{REFERENCES}

Cowperthwaite, J., Weber, M. M., Packer, K. \& Hutner, S. H. (1953). Ann. N.Y. Acad. Sci. 56, 972.

Ford, J. E. \& Hutner, S. H. (1955). Vitam. \& Horm. 13, 101. Hutner, S. H., Bach, M. K. \& Ross, G. I. H. (1956). J. Protozool. 3, 101.

Patterson, E. L., Broquist, H. P., Albrecht, A. M., Saltza, M. H. von \& Stokstad, E. L. R. (1955). J. Amer chem. Soc. 77, 3167.

Sanders, F. \& Seaman, G. R. (1959). J. Bact. (in the Press). Seaman, G. R. \& Sanders, F. (1957). Science, 125, 398.

Swim, H. E. \& Krampitz, L. O. (1953). J. Bact. 67, 418. 